Mary-Ellen Stringer

\title{
Home-spun songs of the subaltern: Writing race in fiction
}

Abstract

Reams of words have already been written on (the bodies of) the marginalised. I argue that the language we use to tell stories of difference has become so saturated with overdetermined and proscriptive meaning that its efficacy in articulating the complexity of life at the margins has been compromised. Language, both academic and creative, has absorbed a sophisticated, quasireligious trope that is shot through with images and references to 'the sacred', and while purporting to 'help' serves to further silence the lived experience of whole sections of the community already struggling to be heard. My aim is to mine a seam of language from the collective imagination that will depict aspects of the real and the now that remain for the most part unspoken, if not unspeakable.

Keywords: sacred, uncanny, race, postcolonial, third space, hybrid subject, song

What songs should be sung in recognition of our national collectivity? - Alexis Wright (Wright 2007: 92)

Alexis Wright's question about song is succinct but expansive. I apply it here as a guiding principle and overarching frame for the thematic preoccupations of my research. To invoke song in the context of explicating a textual work - the question is taken from Wright's article 'On Writing Carpentaria'(Wright 2007) - is to sound a call to the possibilities of creative writing, both within and outside of the text. Song demands a language that consists of voice, rhythm, stillness, silence, decibels, movement, physical resonance, disembodiment, discipline, abandon, and a dexterous empathy, this last because singing is, after all, an interpretive practice. Song comes to life in the ether through a body or bodies, not on a page. It is the language, the mechanics, of the poetics of song, an apparently impossible coherence made out of disparate elements that I want to emulate in a creative piece I am writing for a $\mathrm{PhD}$ titled, A Beggar's Garden.

If that all sounds like idealized romantics, the second half of Wright's question brings me back to pragmatism with a resounding thud. In my search for the most effective language in which to tell my story I am unapologetically driven by political motivations, specifically the politics of race, gender, class and nationhood - by which I mean Benedict Anderson's 'imagined community'; how 'in the minds of each lives the image of their communion' (Anderson 1983: 6). 
Wright does not say 'celebration' of our national collectivity, nor does she say 'in defence of' or 'in contesting', 'commemorating' or 'reconciling' it. She calls for recognition. Further, by coupling the word with the precise phrase 'national collectivity', she casts a net over the nation that is overwhelmingly inclusive; difference is a given.

In the realm of the national imaginary, for my purposes - as a white writer endeavouring to produce a piece of fiction that features race relations is to wade into an intellectual and socio-political quagmire. Australian literature, and cultural and literary criticism, is a dense terrain where the tone of debate ranges from the facile - centred on essentialist racism of the biological and/or cultural variety - to the incomprehensible, posited in the form of vertiginously high post-everything-including-theory theory. The rules of engagement are anarchic one day (shock-jock hate-spewing radio) then circumscribed the next (polite, if passionate discourse conducted under the auspices of the Academy and its loose affiliates, a handful of literary journals). The debate surrounding Kate Grenville's The Secret River (2005) is an obvious example. For an Australian literary text, the novel drew an unprecedented amount of attention in the mainstream press. At the time, the nation was governed by a conservative ideologue who persistently declared 'our' colonial history 'heroic' (Howard 1996) and, where the brutality meted out to the Indigenous peoples was concerned, conceded only to a couple of unsightly 'blemishes' (Howard 1997). The volatile and occasionally rabid response generated by Grenville's novel was trumpeted in the militaristic language of not one but two wars, Culture and History. As if, in any case, the two could be so unproblematically disentangled. As for race, well, don't mention the war.

White people writing race in fiction is a dangerous business. On one hand, to produce texts in which the marginalized, the Indigenous and other outsider subjectivities are conspicuous by their absence is to risk accusations of perpetuating a 'white patrician nationalism' (Davis 2007: 9). The genealogy of this particular identity formation is steeped in a nostalgia that reaches back to the fiction of terra nullius in order to find purchase in the present. One consequence of this reaching back is the persistence of what Graham Huggan has described as a 'self-congratulatory fantasy of a Happy White Australia ... as oblivious to the complexities of modern social interaction as it is amnesiac towards the nation's colonial past' (Huggan 2007: 21). On the other hand, to feature the marginalised, Indigenous or other, a writer can be accused of producing a variation of the same: 'a raced hegemonic formation where nonwhite peoples figure as objects for white concern and as templates on which white "tolerance" is acted out, but are never granted the same privileges as whites, especially the power to speak or act for themselves, except under conditions already circumscribed by white power' (Davis 2007: 14). Germaine Greer's scathing critique of David Malouf's Remembering Babylon (1993) is a case in point. Referring to Malouf's Gemmy character - a white man who'd 'gone native', 'lived black' for years then wandered back into white settlement stuttering, 'Do not shoot ... I am a British object' (Malouf 1993: 3) - Greer railed that the 'only black who is allowed to speak is the fake black' (Greer 1993: 11). However, for a white writer to give voice to the Indigenous, or other outlawed subjects, as often as not translates in critical discourse as 'speaking for' which is equally problematic.

My novel-in-progress, A Beggar's Garden, is not an exploration of race relations as such. However, the central relationship is interracial, between a white mother and her black son who is of African descent. Already I am on shaky ground. It's necessary to be explicit. She has transgressed. She procreated with a black man. A brief synopsis: after a violent episode at the hands of her white husband, my protagonist, Meg, takes her four-year-old 
white daughter and her aforementioned fourteen-year-old son and, in the middle of the night, flees her outer Brisbane suburban home for the anonymity of the city centre. Meg will not go to the police / refuge / hospital. She is convinced that if the three of them become visible to the State her children will be taken away from her. This singular belief understated early in the novel and barely referred to again, dictates all her decisions and therefore the arc of the story. Shadows lurk in this fear of hers; Australia has a less than heroic, thoroughly raced, classed and gendered history of child removal.

In the city Meg and her children join the ranks of the homeless, the internally displaced, among them the mentally ill, Indigenous, the very poor, and disaffected youth for whom the streets are safer than home. My cast of characters is a community unto themselves, a loose collective of the wounded, who, for the most part think of themselves as doing okay, thanks very much. They are the forgotten, or at least the best forgotten, and they know it.

Clearly, I'm of the opinion this song should be sung. The question is, how? To what accompaniment? In what register?

It would be disingenuous to continue without giving some autobiographical information. I have two 'mixed-race' daughters of African ancestry (heritage? blood? I never know what to say). When their father and I separated there followed several years during which, for one reason or another, my young daughters and I became familiar with the milieu of 'the street', though we were never homeless. At one stage I believed the State was going to take my children away from me. Through the networking of the street people my girls were taken in and granted temporary asylum by an unofficial Indigenous community. I've written about this elsewhere (Stringer 2007), the details are not pertinent here. The point is, it struck me then, as it does now over ten years later, that this was an extraordinary, deeply compassionate and wholly lifeaffirming turn of events because it intertwined with a most grotesque State policy and its ongoing consequences.

At one stage in my A Beggar's Garden, Meg's children are hidden by an Indigenous community. I am mindful here of what I interpret to be a caution issued by Deleuze: 'To write is not to recount one's memories and voyages, one's loves and griefs, one's dreams and phantasms. It is the same thing to sin through an excess of reality as through an excess of the imagination' (Deleuze 1997: 227). In context of that caution, while I am not writing autobiography I am attempting through my lived experience to mine a seam of language from the collective imagination that will depict aspects of the real that remain, in 'mainstream' Australia, unspoken if not unspeakable.

In what Wright has called 'the land of disappearing memory' (Wright 2007: 90), how do you speak of the forgotten?

The weak must continually turn to their own ends forces alien to them. - Michel de Certeau (de Certeau 1984: xix)

Amnesia, alienation, displacement, dislocation- these are the conceptual bedrocks of postcolonial literary critique in Australia. In this discourse the trope of displacement or, put another way, the obsession with belonging, of being or not being at home - usually in the landscape - is tethered to the white experience. As Ken Gelder writes: 'it is now commonplace to observe that settler Australians are in fact "unsettled" in a range of ways that speak to 
postcolonial predicaments' (Gelder 2005: 163). To oversimplify, the settler is unsettled by the knowledge that his/her presence in the landscape is predicated on the forced dispossession and displacement of the Indigenous peoples. Any sense of belonging the settler gleans from occupying a patch of earth is always already imbued with the suspicion, acknowledged or not, that the claim to ownership is illegitimate.

Much scholarship in postcolonial literary and cultural criticism features Homi Bhabha's extensive theorising on hybridity and his concept of 'the third space'. The third space has been imagined as a 'means for describing a productive, and not merely reflective, space or encounter ... where new ways of being and innovative kinds of cultural meaning can be brought into existence' (Russell 2006: 3 emphasis in original). In broad terms, the third space has been mobilized to produce a discursive space which 'enables the analysis of various forms of enunciation, rupture, transgression, and subversion' (Russell 2006: 4). The third space, theoretically, accords to the othered - the metaphysically homeless - a place to reside where they are not defined by, nor required to perform a fixed identity dictated by the binary logic of same/different, black/white or us/them. The residents of the third space are the marginalised and are duly constructed as hybrids. With apologies to Bhabha for my oversimplifications, the hybrid is thought of as a productive not derogatory subjectivity, one that disrupts the boundaries of self/other, centre/margin, exile/citizen. Malouf's Gemmy character is one literary example. Toni Morrison's spectral Beloved character is exemplary (1987). Bhabha writes that the hybrid 'reveals the ambivalence at the source of traditional discourses on authority and enables a form of subversion, founded on that uncertainty, that turns the discursive conditions of dominance into the grounds of intervention' (Bhabha 1985: 154). The attraction of Bhabha's theorising is clear; it offers a site from which to address social inequity. The tone of some academic comment that uses the hybrid and the third space verges on euphoric with the hybrid identity being imagined, for instance, as having the capacity to 'function as a "lubricant" for easing cultural friction' (Russell 2006: 4). In principle, I agree. However, I have misgivings. My disquiet is not a reaction to Bhabha's work which I find to be compelling. Rather, I am interested in the uses it has been put to: how, by whom and to what end?

\section{In The Practice of Everyday Life Michel de Certeau differentiates between} what he calls a 'strategy' and a 'tactic'. A strategy, he writes, 'assumes a place that can be circumscribed as proper and thus serve as the basis for generating relations with an exterior distinct from it (competitors, adversaries ... or "objects" of research).' He designates a 'tactic' as a mode of resistance, 'a calculus which cannot count on a "proper" (spatial or institutional localization) ... The place of a tactic belongs to the other' (de Certeau 1984: xix emphasis in original). Applying this equation to current postcolonial literary work I can't help but question the efficacy of an ongoing tendency to position the other as a reified hybrid who is comfortably housed in the third space. There are enormous risks involved in this construction. Having interpellated the other into visibility, the 'proper' institution that is academic discourse then puts the hybrid to work as a 'lubricant' for 'easing cultural conflict'. I perceive no acknowledgment of agency in this equation. Granted, I am not engaging with the specific and complex arguments that constitute postcolonial scholarship and I acknowledge the possibility that any subject who falls under the abstract gaze of academic discourse is potentially robbed of agency. However, some subjects remain more equal than others and, taken as a large body of work, it can appear that white scholars in particular are intent on delineating and defining what constitutes both the hybrid subject and the topography that hybrid traverses. In other words, an endless re-inscription of the other is taking place. Moreover, the emphasis invariably falls on the potential for productive resistance. This 
position strikes me as contradictory given the hybrid subject is imagined to be dispossessed of home and community and granted no agency by the 'proper' instruments of power. Resistance in this postulation begins to look like placid acquiescence to the status quo, and the happy-subversive-hybrid subject a hypothesis that serves to constantly create the third space. Could the sheer bulk of this work and the optimistic tone it adopts operate as a form of banishment? Could the designation of the sign 'hybrid subject' have become, in a strategic sense - belonging to the 'proper' - a form of oppression? Could the sign function as a means to silence, a textual imposition of de Certeau's 'violence of order' (de Certeau 1984: xiv)?

And, crucially, what tactical moves are available to the creative writer attempting to articulate the lived experience of the banished who are obliged to try and carve themselves a 'home' out of the always indeterminate elements of the third space? De Certeau argues that 'a tactic depends on time - it is always on the watch for opportunities that must be seized "on the wing." ... It must constantly manipulate events in order to turn them into "opportunities" (de Certeau 1984: xix). If, as I have suggested, the hybrid in the third space has become so conceptually overdetermined that its potential for subversive intervention has been compromised, then what opportunities exist that might provide its continued use some measure of tactical currency? In context of $A$ Beggar's Garden and its exegetical accompaniment, my position is that it is not the idea of the hybrid that requires manipulation. It is the environment which my raggle-taggle band of outcasts and their homelessness are both being constructed and set adrift in - the Australian literary establishment.

Over a series of articles produced in the last decade, Andrew McCann offers an excoriating but salutary assessment of the state of Australian letters. His arguments read like a lament for lost, refused, bungled and disavowed possibilities. He considers that the "middle-class, middle-brow tone of Australian literary fiction is probably undeniable. The end result of this is the impossibility of a literature capable of questioning its own institutional or ideological function' (McCann 2004: 24). The conservative predilections of Australian literature are never more apparent than in those instances where the relaxed and comfortable middle class literary text engages with Gelder's postcolonial predicaments, notably, in explorations of belonging, home, race and landscape.

The unhomely moment relates the traumatic ambivalences of a personal, psychic history

to the wider disjunctions of political existence. - Homi Bhabha (Bhabha 1994: 11)

On closer inspection, the unsettled settler, as suggested by a multitude of critics, is in fact haunted. The haunted trope winds through relatively recent scholarship by way of Freud's much cited essay 'Das Unheimlich' ('The Uncanny', 1919) in which he defined the uncanny as, among other things, that which 'ought to have remained hidden and yet comes to light' (Freud 1919 [1976]: 623). For Freud the uncanny 'is in reality nothing new or foreign, but something familiar and old-established in the mind that has been estranged only by the process of repression' (Freud 1919 [1976]: 634). Given its etymology, the uncanny is inextricably related to ideas that circulate around the concept of 'home', the German heimlich meaning home, and unheimlich, literally meaning unhomely. The interwoven ideas of a haunted, uncanny 
and/or unhomely 'moment' have become pervasive, if not entrenched, in postcolonial literature and critique.

Indeed, so pervasive are these ghostly imaginings that a counter, though complementary, narrative has developed: what Gelder and Jane Jacobs have called 'discourses of the sacred' (Gelder \& Jacobs 1998: xi). Obviously, 'the sacred' is a vast field of scholarship and I do not have the space here to delve into any complex analysis. However I will suggest that, like Bhabha's hybrid identity in the third space, the sacred in Australia has become a site of confluence where expeditious political concerns of the marginalised are conflated into and subsumed by modes of representation that continually reproduce a homogeneous 'middle-class, middle-brow' cultural landscape. The New Age movement comes to mind with its essentialist platitudes like 'becoming one with the Goddess'. In a more urbane, but I would argue no less platitudinous manifestation, the sacred has been used as a theoretical baseline from which the whole nation, no less, has been subjected to a Jungian psychoanalytic reading by David Tacey in his widely-read and widelycriticised Edge of the Sacred (1995). Both are deficit models that assume 'lack' as the defining precondition, and 'redemption', in one form or another, as the 'cure'.

Tacey insists that 'a sense of almost complete unreality and alienation plagues contemporary life' (Tacey 1995: 150). His solemn suggestion towards achieving a sense of reality and belonging is to become " aboriginalised" from within' (Tacey 1995: 134). And there's the rub. The sacred remains associated with the primitive, animist and, I argue, fetishised Indigenous other - the sacred is raced. Talk about the return of the repressed! Is the collective so bereft, the dominant order so disordered, the magnanimous 'we' so spiritually impoverished that the sacred has been commandeered as a refuge for the privileged, the well-housed, well-fed and well-read? And if that is the case, how can an unspeakable story like my A Beggar's Garden be told, given that it is deliberately designed to conjure that which 'ought to have remained hidden', and that the various parts that make up the whole have already been cast (out) into the otherworldly, the uncanny and the untouchable?

While Tacey and his ilk continue to diagnose the nation with vague and ethereal ailments that fall as a plague on all our houses, the secular society that is mainstream Australia has constructed an unmarked repertoire of the sacred. The idea of 'home' has assumed the conceptual proportions of a sacred site which is still predominantly understood as a place of safety and the proper domain of women and children. Motherhood, particularly the construction of the abstracted but essentialised and much vaunted 'earth mother' and her 'maternal instincts', has assumed sacred status, as has the presumed innocent wisdom of children. The persistence of the link between the Indigenous and the sacred keeps the idea of the noble savage alive. What interests me is the collective's response when home is not safe; when the practice of motherhood looks more like improvised urban warfare and children are wise not because of their tender age but because violent circumstances have forced them to acquire wisdom beyond their years. To date, our response appears to be one of wilful non-recognition. In order to keep our sacred sites - home, mother, child, and the noble savage - unpolluted, we leave our wounded out on the battlefield, collateral damage in the scramble for meaning. A Beggar's Garden is a gesture towards hauling them in.

Whether explicit (the Indigenous sacred) or implicit (mother, child, home) it is the ubiquity of the idea that delivers the sacred as a site ripe for creative manipulation. Conjuring the sacred and grappling with the uncanny are standard devices in Australia's literary canon. So much so that McCann argues: 
the sacred ... is already so well assimilated into habits of reading and thinking that its presence as a literary trope presents few difficulties ... instead of talking up its revelatory or transformative potential, we might be tempted to comment on, if not its banality, then at least its familiarity and the obstinacy of its recurrence. (McCann 2005: 154)

That the sacred already circulates as familiar, mundane and banal presents a salient opportunity. Specifically, it is precisely the familiarity of the sacred that leaves it vulnerable to a guerrilla-style re-write, a tactical skirmish into the heartland of the dominant order's textual territory.

One can institute a zone of proximity with anything, on the condition that one creates the literary means for doing so ... There is no literature without fabulation. -Gilles Deleuze (Deleuze 1997: 227)

The hybrid, the third space, the sacred and the uncanny; Goddesses, ghosts, guerrillas and the forgotten; psycho's and misfits; blacks, battered children, embattled women and the haunted white paternal; outlaws, outsiders, outriders, and the wounded; and throughout all, the connecting tissue that is, if I may be so bold, a universal longing for a safe place, for sanctuary, for 'home'. These are some of the conceptual elements, entities and thematic threads that inform the process of my writing A Beggar's Garden. Any and all of these elements could lend themselves to a gothic rendering, or they could produce a voyeuristic parade of cardboard cut-outs, or worst of all, a mawkishly cute and romanticised vision of the marginalised. My intention is to avoid all these options.

In my search for the language of my novel, as I mapped its structure, narrative moves, central characters and settings, it became apparent that I am writing an archetypal story and grafting it onto the oldest of literary templates. Meg's venture into the domain of the city's homeless can be read as a journey to the Underworld. She is Demeter, who, unaware that the worst has already happened (she has witnessed her son being beaten up by his stepfather) flees an Ogre (her drunken husband) who has got himself into a murderous rage. She takes her beloved son and her precious Persephone down to the Underworld by choice. Along the way our heroine meets: a broken-hearted prince named Slop (he's lost a young daughter in a house fire and cannot now bring himself to live indoors); a Dickensian landlord (the proprietor of an inner city boarding house who wears a toupee and has a nicotine stain travelling up his face from the corner of his lip); a chorus of the Court's fools (a gang of 'street-kids' who have run away from abusive homes and formed a dysfunctional family of their own); an evil witch who tries to steal the children (a do-gooder Alcoholics Anonymous member who calls social services and 'informs' on Meg); a Shakespearean Seer (a complete loony given to dropping pithy quotes at the slightest provocation, anything from the Bible to 'the two Bobs' - Marley and Dylan - and Blake); a fairy Godmother (white, of course, and tough as the toe of a steel-capped boot), employed as the gatekeeper for the indigenes (who manage to live in plain sight and stay under the radar); a wizened native matriarch (she lives on the river bank in a park, gets riotously drunk and orders everybody around) who, under a resigned sufferance but with huge heart supervises a healing ceremony (a jumble of country-and-western songs, hiphop dancing to didgeridoo, and Meg's four-year-old reciting poetry) for their 
mutual friend Slop (he's landed in hospital having been badly bashed by a gang of private-school boy rednecks). The park people then send the heroine on her indeterminate way.

At one stage Meg takes shelter in the State library where she stares at the mudbrown river and cries and cries. She is driven out of a church. She absconds from a lunatic asylum where the police have put her. Her son has his first kiss with a fifteen-year-old prostitute who, fully cognisant of the irony, has adopted the working name, Eve. Meg falls asleep by the river in the Edenic botanic gardens and is woken by her black man-child bearing the gift of a stolen mango. Throughout the novel the bruised and besieged little family criss-cross back and forward by ferry over the ever-constant river, paying the ferryman in nothing but smiles and wit.

The zone of proximity I aim to create with all this familiarity is one of claustrophobia. Despite its ancient template and the weighty symbols and images I am using, the novel is written resolutely and relentlessly in the here and the now. Tactically, I am reclaiming the sacred, the uncanny and the middle-brow-postcolonial-haunted-hybrid, and recasting them in the language of the profane, the secular and the desperately real where flesh-and-blood, albeit textual, humans are hungry and homeless. I am appropriating the cultural texture of the sacred and the archetype in order to question the political meanings and proscriptive properties they have acquired. I'm not writing from a position of righteous sympathy for the other, nor am I writing a dour paean to the marginalised victim. My characters live voraciously, they 'do life' with a vengeance, they do not require my sympathy. What they require is a form.

If what I have described throughout make up the various parts that constitute the literary means of $A$ Beggar's Garden, then the question becomes how to use these devices in such a way that they form a discrete language in which to narrate the story. My intention is to bury the mythological leanings, along with the politics of the story, deep in the writing. So much so that they are invisible to the reader, or conversely, so obvious that they form a kind of slip-way for the narrative, a surface designed for easy passage. Given that the story itself is brutal, the mode of telling needs to be accessible and presented in the most palatable and familiar form. That doesn't mean I intend to let the reader off the hook; quite the opposite. I want the writing to engender a visceral response. I want the reader inside the text, having to confront the same dangers and decisions the characters face. In order to at least attempt to circumvent the reader's escape into the detached comfort that myth, fable or parable can provide, the writing must be clear-eyed, utterly without pity and absolutely grounded in the real, even if that real is bent out of recognisable shape. Mine is a well-trodden path of textual intervention; I am using the master's tools to dismantle his house, or in this case, I am using an archetypal template to subvert the sacred text that is 'home'.

The journey to the Underworld is, of course, the journey to the self, the heart of darkness and all that. To hold onto your child (symbolically, if you will, the aspects of your self you believe to be sacrosanct), would you be, as Meg is, prepared to sit quietly and watch a man die? Walk away from every material possession you had? Sell out every shred of intellectual, physical and spiritual integrity you imagined you possessed and replace it with the basest of survival techniques? Would you run blindfolded along the edge of an abyss? Sing full throttle in a language you don't understand? And having said yes to all of the above would you still have the heart to continue to love?

Song is, and has always been, spun out of spirit. Song forms among the shadows and echoes and traces of speech gone stale or sour or otherwise 
rendered meaningless or dead, or simply not up to the linguistic task at hand. From necessity and with dogged human ingenuity song flies in to fill the void left by a story that is beyond the possibility of language to speak it, but which still demands a hearing. The mythical phoenix, always rising from its own destruction, is a singer after all. The bird is a storyteller; its story is the inextinguishable nature of song. Individual bodies/stories can be silenced but song will always find more flesh to be its conduit.

A voiceless mongrel crew who couldn't afford the rent on the third space even if someone could tell them how to find it - the rent or the space - my characters have no use for middle-brow sympathetic hand-wringing operetta. In scope $A$ Beggar's Garden is high-brow, high opera, but in sensibility it resides in the mosh pit of an unknown garage band. And, as everybody knows, you can be stone broke and tone deaf and still thrive in rock and roll. I want to write my story in the spirit of a raucous twelve bar blues; slow, direct, loose, repetitious in rhythm and refrain, simple to the point of artless, a hymn without religious connotations. Above all, I hope to scatter the writing with what is known in musical vernacular as 'grace notes'. These are the notes of near silence, the pause, the time to breathe; the space for grace.

\section{Works Cited}

Anderson, B 1983 Imagined Communities: Reflections on the Origins and Spread of Nationalism. London, Verso return to text

Bhabha, H 1985 'Signs Taken for Wonders: Questions of Ambivalence and Authority under a Tree Outside Delhi, May 1817’, Critical Inquiry 12, 1: 144-165 return to text

Bhabha, H 1994 The Location of Culture. London, Routledge return to text

Davis, M 2007 'The Clash of Paradigms: Australian Literary Theory after Liberalism', JASAL 7: 7-31 return to text

De Certeau, M 1984 The Practice of Everyday Life. Berkeley, University of Minnesota Press return to text

Deleuze, G 1997 'Literature and Life', Critical Inquiry 23, 2: 225-230 return to text

Freud, S 1919 [1976] 'The Uncanny', New Literary History 7, 3: 619-645 return to text

Gelder, K 2005 'When the imaginary Australian is not uncanny: Nation, psyche and belonging in recent Australian cultural criticism and history', Journal of Australian Studies 29, 86: 161173 return to text

Gelder, K \& JM Jacobs 1998 Uncanny Australia: Sacredness and Identity in a Postcolonial Nation. Carlton South, Melbourne University Press return to text

Greer, G 1993 'Malouf's Objectionable Whitewash', The Age (3 November): 11 return to text Grenville, K 2005 The Secret River. Melbourne, Text Publishing return to text

Howard, J 1996 'The Liberal Tradition: the Beliefs and Values Which Guide the Federal Government', Sir Robert Menzies Lecture Trust http://menzieslecture.org/1996.html (accessed 4 June 2011) return to text

Howard, J 1997 'Australian Reconciliation Convention 1997: Opening address by the Prime Minister', Indigenous Law Resources: Reconciliation and Social Justice Library http://www.austlii.edu.au/au/other/IndigLRes/car/1997/4/pmspoken.html (accessed 4 June 2011) return to text

Huggan, G 2007 Australian Literature: Postcolonialism, Racism, Transnationalism. Oxford, Oxford University Press return to text 
Malouf, D 1993 Remembering Babylon. New York, Pantheon Books return to text

McCann, A 2004 'How To Fuck A Tuscan Garden: A note on literary pessimism', Overland 177: $22-24$ return to text

McCann, A 2005 'The obstinacy of the sacred', Antipodes 19, 2: 152-157 return to text

Morrison, T 1987 Beloved. London, Chatto \& Windus return to text

Russell, L (ed) 2006 Boundary Writing: An Exploration of Race, Culture, and Gender Binaries in Contemporary Australia. Honolulu, University of Hawai'i Press return to text

Stringer, M-E 2007 'The Sky as Common Ground', Overland 189: 16-21 return to text

Tacey, D 1995 Edge of the Sacred: Transformation in Australia. North Blackburn, Victoria, HarperCollins return to text

Wright, A 2007 'On Writing Carpentaria', Heat 13: 79-95 return to text

Mary-Ellen Stringer is currently writing her PhD at Griffith University. She completed her undergraduate and honours degrees at Southern Cross University where she received the Australian Cultural Studies Prize and the University Medal. Among her publications are fiction in Meanjin and creative non-fiction in Overland. In her life BC (before children) she was a rock and roll blues singer for twenty years.

\section{TEXT}

Vol 15 No 2 October 2011

http://www.textjournal.com.au

Editors: Nigel Krauth \& Kevin Brophy

Text@griffith.edu.au 